\title{
Predictors of Seroprevalence of Hepatitis C Infection among Health Care Workers in Nigeria; A Year after Post Implementation of Nigeria's National Hepatitis Prevention Policy
}

\author{
Theresa Nwagha ${ }^{1}$, Babatunde I Omotowo ${ }^{2}$, Uchenna N Ijoma ${ }^{3}$, Ijeoma A Meka ${ }^{4}$, Obinna D Onodugo ${ }^{3}$, \\ Ebele V Okoli ${ }^{2}$, Chinwe L Onyekonwu ${ }^{5}$, Olive Obienu ${ }^{3}$, Anne Chigedu $\mathrm{Ndu}^{2} \&$ Emmanuel O Ugwu $^{6}$ \\ ${ }^{1}$ Department of Haematology, University of Nigeria Teaching Hospital, Ituku-Ozalla, Enugu, Nigeria \\ ${ }^{2}$ Department of Community Medicine, University of Nigeria Teaching Hospital, Ituku-Ozalla, Enugu, Nigeria \\ ${ }^{3}$ Department of Medicine, University of Nigeria Teaching Hospital, Ituku-Ozalla, Enugu, Nigeria \\ ${ }^{4}$ Department of Chemical Pathology, University of Nigeria Teaching Hospital, Ituku-Ozalla, Enugu, Nigeria \\ ${ }^{5}$ Department of Dermatology, University of Nigeria Teaching Hospital, Ituku-Ozalla, Enugu, Nigeria \\ ${ }^{6}$ Department of OBGYN University of Nigeria Teaching Hospital, Ituku-Ozalla, Enugu, Nigeria \\ Correspondence: Babatunde Omotowo, MBBS MPH, FWACP, Department of Community Medicine UNTH \\ Ituku Ozalla, Nigeria. Tel: 234-806-581-9918.
}

Received: March 21, 2021 Accepted: April 19, $2021 \quad$ Online Published: May 31, 2021

doi:10.5539/gjhs.v13n7p32 URL: https://doi.org/10.5539/gjhs.v13n7p32

\begin{abstract}
Background: Hepatitis C virus (HCV) infection is a global public health issue. Health care workers (HCWs) are particularly at risk. Nigeria hepatitis prevention policy aims to achieve country wide elimination of hepatitis through early detection using mass screening with life-style modifications of "at risk population" which are key preventive strategies.
\end{abstract}

Aim: To determine the seroprevalence of HCV infection among HCWs in a large regional referral hospital in Nigeria.

Methods: A hospital-based descriptive cross-sectional study (hepatitis mass screening) was done at the University of Nigeria Teaching Hospital, Enugu, Nigeria between July and August 2016. Non-randomised sampling was used. Blood samples were assayed for antibodies to HCV. Data on knowledge, risk factors and mode of transmission were collected using a structured, pre-validated, pretested, questionnaire and analysed using SPSS version 20.

Results: A total of 3132 out of $5144(60.9 \%)$ HCWs participated in the study. The seroprevalence of hepatitis C among UNTH staff was $0.90 \%$ (28/3132). The mean knowledge score of $68.95 \% \pm 24.23$ and $56.70 \pm 17.25$ translates to fair knowledge level about mode of transmission and risk of transmission of hepatitis $\mathrm{C}$ among $\mathrm{HCWs}$, respectively. There was no reported case of hepatitis $\mathrm{B}$ and $\mathrm{C}$ co-infection. Females HCWs had highest sero-prevalence for $\mathrm{HCV} 17 / 5144(0.33 \%)(\mathrm{P}=0.164$, AOR $=1.76,95 \% \mathrm{CI}=0.431-2.413)$.

Conclusion: This study found a low seropositivity of HCV among HCWs. A pointer to the possible success of the hospital-based education awareness programme, an implementation of Nigeria's national hepatitis prevention policy.

Keywords: Hepatitis C Virus, healthcare workers, seroprevalence, health policy

\section{Introduction}

Hepatitis $\mathrm{C}$ virus (HCV) infection is a major health issue of global proportions which requires widespread active interventions for its prevention and control. This is no surprise as the spread of HCV (based on the rate of development of molecular diversity) can be estimated to date back about 500-2000 years (Smith et al., 1995). The HCV was first identified in 1989 though it had been prevalent for many decades (Thorburn et al., 2001). The origin of the infection had been connected to mass anti-schistosomal parenteral treatment campaigns conducted in the 1960s-80s using insufficiently sterilized injection material (Franco, Bagnato, Marino, Meleleo, Serino, Zaratti, et al., 2012). Globally in 2015, over 70 million people had chronic HCV infection (World Health Organization, 2017) with almost 500000 deaths per year (Franco et al., 2012). Almost one fifth of the world's cases of HCV occur in 
Africa (Dore, Ward, \& Thursz, 2014). Sub-Saharan Africa has a moderate incidence rate of $2.8 \%$ with over 8 million people infected (Mohd Hanafiah, Groeger, Flaxman, \& Wiersma, 2013). Nigeria has a prevalence rate of $2.1 \%$ with over 3 million people infected with HCV (Lavanchy, 2011). The major burden from HCV infection comes from sequelae from chronic infection (Perz, Armstrong, Farrington, Hutin, \& Bell, 2006). Globally, estimates indicate that three to four million persons are newly infected each year, while 170 million people are chronically infected. Approximately $75-85 \%$ of $\mathrm{HCV}$-infected persons will progress to chronic HCV infection, and are at risk of developing extrahepatic manifestations, compensated and decompensated cirrhosis, and hepatocellular carcinoma (HCC) (Chen, \& Morgan, 2006). Antibodies to HCV (anti-HCV) are a commonly available marker of HCV infection (Franco et al., 2012). The mode of transmission is parenteral, most often through injections, especially when needle sharing is involved, occupational exposure among HCWs, sexually transmitted especially when multiple partners are involved (Wasley, Miller, \& Finelli, 2007). Infection by blood transfusion is now somewhat rare especially where quality mandatory blood screening is done. Perinatal transmission is also very uncommon, and the risk of vertical transmission is $6 \%$ in mothers who are only HCV positive (Watanabe Saito et al., 2003). There is no vaccine or postexposure prophylaxis for HCV infection (Hughes \& Henderson, 2016).

The incidence of HCV seroconversion from occupational hazard in health care workers is inconclusive, with figures ranging from 0 to $9.7 \%$ (Coppola et al., 2016). The focus is now on the risk of contracting HCV infection. Without an effective active immunization, the primary prevention strategies against HCV are mainly on advocating safe injection and blood transfusion practices. With anti-HCV therapy, advanced liver disease is largely preventable but largely constrained by the high cost of diagnostic tests and few personnel with knowledge and skills to provide these treatments. Secondary prevention strategies against advanced liver disease; screening for early detection and promotion of health life choices in terms of alcohol ingestion remain key cost-effective public health tools (Kim et al., 2010; Mitchell et al., 2010; Peters et al., 2010) especially in resource constrained nations like Nigeria.

Few studies have been done on HCV sero-prevalence in Nigeria with reports coming from non-representative studies conducted among high-risk groups including pregnant women receiving ante natal care (Anaedobe, Nwadike, \& Fowotade, 2016; Onwere et al., 2011), doctors and dentists (Olubuyide et al., 1997), blood donors (Ayolabi et al., 2006), diabetics (Adegoke et al., 2008), children (Eke et al., 2016) and undergraduates (Jemilohun, Oyelade, \& Oiwoh, 2014). At the time of the study, there are few studies on seroprevalence of HCV infection in health care workers in a tertiary health institution in Nigeria. This study aims to assess the knowledge and seroprevalence of HCV infection among HCWs in University of Nigeria Teaching Hospital, a major referral hospital in South Eastern Nigeria.

\section{Materials and Methods}

\subsection{Study Design}

This was a hospital-based cross-sectional descriptive study carried out at the University of Nigeria Teaching Hospital (UNTH) Enugu.

\subsection{Study Area}

UNTH is a 576 bedded hospital with staff of approximately 5144. It is a major referral tertiary hospital located in the South-East of Nigeria which offers family medicine as well specialist medical and surgical consultations, laboratory, blood bank, dental and mortuary services.

\subsection{Study Population}

The categories of health care workers include; doctors, nurses, pharmacist, laboratory technologists and others ancillary staff like; health assistants, health admin officers, dental therapists and mortuary attendants whose duties range from handling of corpses, equipment cleans ups, sample handling transportation and trash disposal.

\subsection{Sampling}

Convenience sampling method was used recruit $\mathrm{HCW}$ who presented for the free hospital organized hepatitis $\mathrm{C}$ virus screening programme and consented to the study. Inclusion criteria include male or female between the ages of 18-70 years. Those members of staff who had jaundice, alcoholics, known liver disease, chronic inflammatory/debilitating illness or have been transfused less than 3months before this study were excluded from the study.

\subsection{Sample Size Estimation}

All healthcare workers who consented could participate in the study. A total 3132 (3132/5144, 62.6\%) HCWs 
participated in the study.

\subsection{Data Collection}

Hepatitis $\mathrm{C}$ mass screening is not routinely done in hospital. For this programme, hospital staff were informed and pre-sensitized about the free hepatitis screening programme two weeks prior to the commencement via internal memo, posters, handbills, emails, SMS messages and organized awareness campaigns at strategic locations using public address systems. The programme schedule involved different departments to ensure adequate coverage.

For this study, the primary outcome variables of interest were the prevalence of viral hepatitis $\mathrm{C}$ infections amongst HCWs. Potential effect modifiers assessed for included knowledge on transmission and risk factors of hepatitis $\mathrm{C}$ infection.

A pre-validated, pre-tested structured questionnaire were administered to study participants in their preferred language (Igbo or English). The questionnaire was designed wholly by the authors for the study and independently assessed by a public health physician not involved in the study. The questionnaire was then pre-tested on a group of $50 \mathrm{HCWs}$ who were not included in the study; doctors (20), nurses (10), scientists(5) pharmacists(5) , health assistants(5) and administrative staff(5) in a neighbouring hospital, Enugu State University Teaching hospital Enugu to identify most valid questions that will help achieve our objectives. Further reviews were made to develop a final questionnaire. The questionnaire had two sections and 17 questions, 7 on socio-demographic characteristics of respondents and 10 on the knowledge of mode of transmission and risk factors of HCV infection. The questionnaire was translated into the Igbo language and back translated into English by two independent Igbo scholars.

Knowledge of HCV infection was assessed by 10 multiple-choice questions. For each respondent, the percentage of correct answers was calculated as a representative of knowledge score. For participant, score of questions was summed up and converted into percentage to represent the composite knowledge score. The scores were graded as poor knowledge (scores $49.9 \%$ and below), fair knowledge (scores between 50 to $69.9 \%$ ) and good knowledge (scores $70 \%$ and above). Cronbach alpha of the questionnaire was 0.85 .

\subsection{Procedure for Blood Collection}

Venepuncture was done by hospital phlebotomists trained for the study. A $4 \mathrm{ml}$ venous blood sample was collected aseptically, by venepuncture into an EDTA bottle and allowed to stand. Clear plasma separated from the red cells on standing was then extracted. Presence of antibody to HCV (anti-HCV) was determined using HCV chromatographic immunoassay rapid test strips (Biotest, China). These are in vitro qualitative one-step chromatographic immunoassays for anti-HCV detection and the tests were carried out and the test quality controlled using positive and negative control samples according to the manufacturer's instructions. The anti-HCV detection kit has sensitivity of $99.1 \%$ and specificity of $99.5 \%$.

\subsection{Personnel and Training}

Adhoc research assistants, university graduates with experience in data collection, and phlebotomists were recruited and trained for one week on questionnaire administration, sample collection and testing by the research team consisting of gastroenterologists, public health physicians and haematologists using IEC tools like power point presentation, simulations demonstrations and group discussions. The training was held one week before the commencement of the hospital wide screening programme. The objective were informed consent process, quality data collection and sample collection

\subsection{Data Analysis}

Data from completed questionnaires were cleaned up to minimize errors, duplication and entered in Statistic Package for the Social Sciences (SPSS version 22.0, IBM SPSS version 22.0 (IBM Corp, Armonk, NY, USA)) for analysis. Characteristics of the participants were presented as simple frequency tables. Other results were presented in form of tables. In testing for associations, Chi-square statistics was used. Variables which reached statistical significance in the bivariate models were included in the multivariate analysis. Strength of association was measured using Odds ratio and statistical significance assessed using P-values and $95 \%$ confidence intervals for odds ratio. For all analyses, $\mathrm{p}$-values of $<0.05$ were considered statistically significant.

\subsection{Key Outcomes}

The key outcome measure was seroprevalence of hepatitis C among HCWs while secondary outcome measures included their knowledge base of hepatitis $\mathrm{C}$ and its mode of transmission. 


\subsection{Ethical Considerations}

The study was approved by UNTH management and the study protocol was reviewed and approved by UNTH Health Research and Ethics Committee. Informed consent procedure involved signing of informed consent forms by participants after educating them on the purpose of the study, possible outcomes of the screening and available options to be taken depending on the outcome of the screening. Anonymity of data was done with number codes.

\section{Results}

A total of 3132 out of 5144 health care workers of UNTH were screened for. The ages of participants ranged from $18-75$ years with a mean age of $39.4 \pm 9.6$ years. Majority of them were between ages 31 to 60 years $2505(79.9 \%)$, while only $23(0.7 \%)$ were above 60 years old. About three quarters $2237(71.4 \%)$ had tertiary education while 2174 (69.4\%) were married. Doctors, nurses, pharmacists were 297 (9.5\%), $580(18.5 \%)$ and $46(1.5 \%)$ respectively. Majority 1771 (56.5\%) have worked in the hospital for duration of 1 to 10 years (Table 1).

Table 1. Socio-demographic characteristics of the respondents

\begin{tabular}{|c|c|c|c|}
\hline Variables & Categories & Frequency & Percentage \\
\hline \multirow{2}{*}{ Sex } & Male & 951 & 30.4 \\
\hline & Female & 2181 & 69.6 \\
\hline \multirow{6}{*}{ Age (Years) } & $<20$ & 12 & 0.4 \\
\hline & $20-30$ & 592 & 18.9 \\
\hline & $31-40$ & 1151 & 36.7 \\
\hline & $41-50$ & 922 & 29.5 \\
\hline & $51-60$ & 432 & 13.8 \\
\hline & $>60$ & 23 & 0.7 \\
\hline \multirow{5}{*}{ Education Level } & No formal education & 11 & 0.4 \\
\hline & Primary & 229 & 7.3 \\
\hline & Secondary & 626 & 20.0 \\
\hline & Tertiary & 2237 & 71.4 \\
\hline & Vocational & 29 & 0.9 \\
\hline \multirow{4}{*}{ Marital status } & Married & 2174 & 69.4 \\
\hline & Single & 869 & 27.7 \\
\hline & Separated & 11 & 0.4 \\
\hline & Widowed & 78 & 2.5 \\
\hline \multirow{5}{*}{ Job category } & Doctor & 297 & 9.5 \\
\hline & Nurses & 580 & 18.5 \\
\hline & Pharmacist & 46 & 1.5 \\
\hline & Laboratory scientists /Technologists & 90 & 2.9 \\
\hline & Health clerks, Dental therapists, Health attendants & 2,119 & 67.6 \\
\hline \multirow{4}{*}{ Duration of service } & $<1$ year & 263 & 8.3 \\
\hline & $1-5$ Years & 931 & 29.8 \\
\hline & $>5-10$ Years & 840 & 26.8 \\
\hline & $>10$ Years & 1,098 & 35.1 \\
\hline
\end{tabular}

Most Participants showed a good knowledge for mode of transmission 2691/3132(85.9\%) and risk factors for transmission of hepatitis 1776/3132(56.7\%) respectively, See Table 3.

Most of the participants were aware of hepatitis C 3042/3132 (97.1\%) The commonest sources of information 
were radio $2251 / 3132(71.9 \%)$, and health workers $2160 / 3132(70.0 \%)$. Majority $2180 / 3132(69.6 \%)$ knew that blood transfusion is a mode of transmission, while $386 / 3132(12.3 \%)$ believed that it can be transmitted by drinking contaminated water. Less than half of participants 1420/3132 (45.3\%) and 1528/3132 (48.8\%) believed that multiple sexual partners and sharing of needles respectively are risk factors. Those who believed that breastfeeding, and body contact are risk factors were 593/3132 (18.9\%). (Table 2)

The seroprevalence of hepatitis C among UNTH staff was $0.90 \%$ (28/3132). Of $3132 \mathrm{HCWs}$ screened, majority of those that tested positive to hepatitis $\mathrm{C}$ antibodies $89.2 \%(25 / 28)$ were heath assistants, health admin officers, dental therapists, and mortuary attendants. The minority, $10 \%(3 / 28)$ were doctors and nurses. None of laboratory technologists.

Table 2. Knowledge, mode of transmission and risk factors of hepatitis C infection

\begin{tabular}{|c|c|c|c|c|}
\hline \multirow{2}{*}{ Variables } & \multicolumn{2}{|c|}{ Correct response } & \multicolumn{2}{|c|}{ Incorrect response } \\
\hline & $\mathrm{N}$ & $\%$ & $\mathrm{~N}$ & $\%$ \\
\hline Previous source of information about hepatitis & 1003 & 32.0 & 2129 & 68. \\
\hline Heard of hepatitis & 3042 & 97.1 & 90 & 2.9 \\
\hline Heard from Radio & 2251 & 71.9 & 881 & 28.1 \\
\hline From Health Worker & 2160 & 70.0 & 972 & 30.0 \\
\hline From Television & 642 & 20.5 & 2490 & 79.5 \\
\hline From Print Media & 515 & 16.4 & 2617 & 83.6 \\
\hline From Family Member & 305 & 9.7 & 2827 & 90.3 \\
\hline Mode of transmission & \multicolumn{2}{|c|}{ Correct response } & \multicolumn{2}{|c|}{ Incorrect response } \\
\hline Shaking of hands & 84 & 2.7 & 3048 & 97.3 \\
\hline Needle prick & 1322 & 42.2 & 1810 & 57.8 \\
\hline Blood transfusion & 2180 & 69.6 & 952 & 30.4 \\
\hline Heat & 209 & 6.7 & 2923 & 93.3 \\
\hline Sexual intercourse & 1532 & 48.9 & 1600 & 51.1 \\
\hline Drinking contaminated water & 386 & 12.3 & 2746 & 87.7 \\
\hline Sharing of sharp objects such as needles, razors et & 1489 & 47.5 & 1643 & 52.5 \\
\hline Contamination from surfaces & 572 & 18.3 & 2560 & 81.7 \\
\hline \multirow{2}{*}{ Risk factors } & \multicolumn{2}{|c|}{ Correct response } & \multicolumn{2}{|c|}{ Incorrect response } \\
\hline & $\mathrm{N}$ & $\%$ & $\mathrm{~N}$ & $\%$ \\
\hline Blood transfusion & 2134 & 68.1 & 998 & 31.9 \\
\hline Multiple sexual partners & 1420 & 45.3 & 1712 & 54.7 \\
\hline Sharing of needles & 1528 & 48.8 & 1604 & 51.2 \\
\hline Occupational exposure & 1259 & 40.2 & 1873 & 59.8 \\
\hline Others e.g Breast feeding, body contact etc & 593 & 18.9 & 2539 & 81.1 \\
\hline
\end{tabular}

Table 3. The grading of overall knowledge

\begin{tabular}{ccccccc}
\hline \multirow{2}{*}{ Knowledge level } & \multicolumn{2}{c}{ Mode of transmission* } & \multicolumn{2}{c}{ Risk of transmission** } & \multirow{2}{*}{$\mathbf{X}^{\mathbf{2}}$} & P-Value \\
\cline { 2 - 5 } & $\mathbf{N}$ & $\mathbf{\%}$ & $\mathbf{N}$ & $\mathbf{\%}$ & \\
\hline Poor Knowledge & 441 & 14.1 & 1356 & 43.3 & & \\
Fair Knowledge & 520 & 16.6 & 708 & 22.6 & 1.078 & $<0.001$ \\
Good Knowledge & 2171 & 69.3 & 1068 & 34.1 & & \\
Total & 3132 & 100 & 3132 & 100 & \\
\hline
\end{tabular}




\subsection{Factors Associated with Hepatitis C Status}

Binary logistic regression analysis was performed to assess factors associated with Hepatitis $\mathrm{C}$ virus infection. Variables which reached a statistical significance of $\leq 0.2$ in the bivariable models (see Table 4) were included in the multivariable analysis. The statistical level of $<0.2$ was chosen to capture enough population for multivariate analysis.

Table 4. Factors associated with Hepatitis C Status among participants ( $\mathrm{N}=3132)$ (Bivariate analysis)

\begin{tabular}{|c|c|c|c|c|c|c|}
\hline \multirow{3}{*}{ Variable } & \multicolumn{4}{|c|}{ Hepatitis C Status } & \multirow{3}{*}{$\operatorname{COR}(95 \% \mathrm{CI})$} & \multirow{3}{*}{ P Value } \\
\hline & \multicolumn{2}{|c|}{ Positive } & \multicolumn{2}{|c|}{ Negative } & & \\
\hline & $\mathbf{N}$ & $\%$ & $\mathbf{N}$ & $\%$ & & \\
\hline \multicolumn{7}{|l|}{ Sex } \\
\hline Male & 11 & 1.2 & 940 & 98.8 & 1.00 & \\
\hline Female & 17 & 1.8 & 2164 & 99.2 & $1.94(0.789-3.512)$ & 0.362 \\
\hline \multicolumn{7}{|c|}{ Age group (Years) } \\
\hline$<\mathbf{3 0}$ & 2 & 0.3 & 602 & 99.7 & 1.00 & \\
\hline $31-40$ & 9 & 0.8 & 1142 & 99.2 & $1.63(1.353-1.794)$ & 0.003 \\
\hline $41-50$ & 14 & 1.6 & 908 & 98.4 & $0.87(0.563-1.549)$ & 0.186 \\
\hline $51-60$ & 3 & 0.7 & 452 & 99.3 & $1.31(.278-3.947)$ & 0.137 \\
\hline \multicolumn{7}{|l|}{ Marital status } \\
\hline Married & 20 & 0.9 & 2154 & 99.1 & 1.00 & \\
\hline Single & 7 & 0.8 & 862 & 99.2 & $1.40(1.235-1.792)$ & 0.003 \\
\hline Separated & 0 & 0 & 11 & 100 & $1.74(0.164-3.830)$ & 0.196 \\
\hline Widowed & 1 & 1.3 & 77 & 98.7 & $1.93(0.074-2.627)$ & 0.172 \\
\hline \multicolumn{7}{|c|}{ Educational level } \\
\hline Primary & 7 & 2.9 & 233 & 97.1 & 1.00 & \\
\hline Secondary & 8 & 1.3 & 618 & 98.7 & $4.38(1.517-4.107)$ & 0.005 \\
\hline Tertiary & 13 & 0.6 & 2253 & 99.4 & $1.12(0.730-3.676)$ & 0.352 \\
\hline \multicolumn{7}{|c|}{ Professional Categories } \\
\hline Doctors & 1 & 0.3 & 296 & 99.7 & 1.00 & \\
\hline Nurses & 2 & 0.3 & 578 & 99.7 & $1.63(0.579-3.592)$ & 0.261 \\
\hline Pharmacists & 0 & 0 & 46 & 100 & $1.41(0.179-5.321)$ & 0.145 \\
\hline Lab Scientists & 0 & 0 & 90 & 100 & $0.74(1.478-3.736)$ & 0.034 \\
\hline Others & 25 & 1.2 & 2094 & 98.8 & $1.48(0.857-6.627)$ & 0.278 \\
\hline \multicolumn{7}{|c|}{ Duration of work in the hospital } \\
\hline$<1$ Year & 3 & 1.1 & 260 & 98.9 & 1.00 & \\
\hline 1-5 Years & 7 & 0.8 & 924 & $99 . \mathrm{s} 2$ & $0.58(0.483-2.789)$ & 0.175 \\
\hline$>5-10$ Years & 9 & 1.1 & 831 & 98.9 & $0.34(0.173-4.067)$ & 0.158 \\
\hline$>10$ Years & 9 & 0.8 & 1089 & 99.2 & $0.29(0.602-4.863)$ & 0.182 \\
\hline \multicolumn{7}{|c|}{ Any previous training? } \\
\hline No & 26 & 1.2 & 2198 & 98.8 & 1.00 & \\
\hline Yes & 2 & 0.2 & 1001 & 99.8 & $0.67(0.073-0.641)$ & 0.031 \\
\hline
\end{tabular}


Table 5. Factors associated with Hepatitis $\mathrm{C}$ status among participants ( $\mathrm{N}=3132$ )

\begin{tabular}{|c|c|c|c|c|c|c|}
\hline \multirow{3}{*}{ Variable } & \multicolumn{4}{|c|}{ Hepatitis C Status } & \multirow{3}{*}{ AOR $(95 \% C I)$} & \multirow{3}{*}{ P Value } \\
\hline & \multicolumn{2}{|c|}{ Positive } & \multicolumn{2}{|c|}{ Negative } & & \\
\hline & $\mathbf{N}$ & $\%$ & $\mathbf{N}$ & $\%$ & & \\
\hline \multicolumn{7}{|l|}{ Sex } \\
\hline Male & 11 & 1.2 & 940 & 98.8 & 1.00 & \\
\hline Female & 17 & 1.8 & 2164 & 99.2 & $1.76(0.431-2.413)$ & 0.164 \\
\hline \multicolumn{7}{|c|}{ Age group (Years) } \\
\hline$<\mathbf{3 0}$ & 2 & 0.3 & 602 & 99.7 & 1.00 & \\
\hline $31-40$ & 9 & 0.8 & 1142 & 99.2 & $0.16(1.458-1.748)$ & 0.004 \\
\hline $41-50$ & 14 & 1.6 & 908 & 98.4 & $0.79(0.862-1.896)$ & 0.135 \\
\hline $51-60$ & 3 & 0.7 & 452 & 99.3 & $0.38(0.426-3.837)$ & 0.182 \\
\hline \multicolumn{7}{|l|}{ Marital status } \\
\hline Married & 20 & 0.9 & 2154 & 99.1 & 1.00 & \\
\hline Single & 7 & 0.8 & 862 & 99.2 & $1.01(0.535-1.792)$ & 0.385 \\
\hline Separated & 0 & & 11 & 100 & $0.64(0.084-4.760)$ & 0.782 \\
\hline Widowed & 1 & 1.3 & 77 & 98.7 & $0.53(0.064-3.519)$ & 0.639 \\
\hline \multicolumn{7}{|c|}{ Educational level } \\
\hline Primary & 7 & 2.9 & 233 & 97.1 & 1.00 & \\
\hline Secondary & 8 & 1.3 & 618 & 98.7 & $3.87(1.717-8.467)$ & 0.002 \\
\hline Tertiary & 13 & 0.6 & 2253 & 99.4 & $1.32(0.830-5.400)$ & 0.216 \\
\hline \multicolumn{7}{|c|}{ Professional Categories } \\
\hline Doctors & 1 & 0.3 & 296 & 99.7 & 1.00 & \\
\hline Nurses & 2 & 0.3 & 578 & 99.7 & $0.93(0.582-3.946)$ & 0.278 \\
\hline Pharmacists & 0 & 0 & 46 & 100 & $0.64(0.079-4.821)$ & 0.386 \\
\hline Lab Scientists & 0 & 0 & 90 & 100 & $1.42(0.468-5.735)$ & 0.756 \\
\hline Others & 25 & 1.2 & 2094 & 98.8 & $0.83(0.931-6.641)$ & 0.462 \\
\hline \multicolumn{7}{|c|}{ Duration of work in the hospital } \\
\hline$<1$ Year & 3 & 1.1 & 260 & 98.9 & 1.00 & \\
\hline 1-5 Years & 7 & 0.8 & 924 & 99.2 & $0.76(0.613-4.769)$ & 0.485 \\
\hline$>5-10$ Years & 9 & 1.1 & 831 & 98.9 & $0.47(0.346-2.783)$ & 0.698 \\
\hline$>10$ Years & 9 & 0.8 & 1089 & 99.2 & $0.36(0.302-7.258)$ & 0.792 \\
\hline \multicolumn{7}{|c|}{ Any previous training? } \\
\hline No & 26 & 1.2 & 2198 & 98.8 & 1.00 & \\
\hline Yes & 2 & 0.2 & 1001 & 99.8 & $0.56(0.068-0.745)$ & 0.034 \\
\hline
\end{tabular}

Summary statistics (see Table 5) showed that after adjusting for sex, marital status, educational level, professional categories, duration of work in the hospital, and previous training, the odds for hepatitis $\mathrm{C}$ decreased with increasing age of the participants. The odds were $84 \%$ lower among participants that were aged 31-40 years compared to those below age of 30 years (AOR:0.16; 95\%CI:1.458 - 1.748; P:0.004.)

The odds were $44 \%$ lower among participants that had previous training than those were not trained (AOR:0.56; 95\% CI:0.068-0.745; P:0.034). The odds for hepatitis $\mathrm{C}$ decreased with increasing duration of work in the hospital. Odds for hepatitis $\mathrm{C}$ was $24 \%$ lower for those who had work for between 1-5 years (AOR:0.76; 
95\%CI:0.613-4.769; P:0.485). Predictors of hepatitis C seroprevalence were educational levels, professional categories, and previous specific training on hepatitis $\mathrm{C}$ virus.

\section{Discussion}

$\mathrm{HCV}$ is a common cause of occupational blood-borne disease. It transmitted from patients to HCWs and frequently leads to a chronic asymptomatic carrier condition for a long time before the development of symptomatic liver disease (Thorburn, Dundas, McCruden, Cameron, Goldberg, Symington et al, 2001; Deuffic-Burban, Delarocque-Astagneauc, Abiteboul, Bouvet \& Yazdanpanah, 2011). Therefore, HCWs with HCV infection may be unaware of their disease or carrier condition and infect other persons such as their families or patients (Thorburn, Dundas, McCruden,Cameron, Goldberg, Symington et al, 2001).

Our results suggest a low HCV seroprevalence of $0.90 \%$ among an indigenous Nigerian HCWs population. This was comparable to reports from similar studies in Ibadan and Ogbomoso in Nigeria with a reported prevalence as low as $0.4 \%$ (Olubuyide et al., 1997) to as high as $11 \%$ (Jemilohun, Oyelade \& Oiwoh, 2014) respectively. It is, however, low when compared to figures from West sub-Sahara Africa; Benin, Burkina Faso, Cote d'Ivoire, Cameroon, Cape Verde, Ghana, Guinea,The Gambia, Guinea-Bissau, Liberia, Mali, Mauritania, Niger, Nigeria, Senegal, Saint Helena, Sierra Leone, Sao Tome and Principe, Chad, Togo (Mohd Hanafiah, Groeger, Flaxman, \& Wiersma, 2013) as reported in a global epidemiological report by Mohd et al The prevalence is comparable to reports from other parts in Africa such as 1.3\% in Rwanda (Kateera et al., 2015) but high when compared to reports from other parts of the world such as the Netherlands 0.14\% (Okasha et al., 2015), West Scotland 0.28\% (Thorburn et al., 2001) and none in Iran (Zaaijer, Appelman, \& Frijstein, 2012). The results showed a higher prevalence rate in females than males comparable to a similar study done in Keffi, Nigeria with reported higher HCV prevalence rate in females than males (Pennap, Yakubu, Odula, Joseph, \& Forbi, 2010). The predilection for female gender in our hospital based cannot be explained and further studies are needed to better understand this relationship. Some gender related cultural practices like female genital mutilation, piercing, or and poor health seeking behaviours in our environment as reported (Nail, Eltiganni \& Islam, 2008) could be contributory. Equally, the highest number with HCV antibodies were between 41-50 years, this was also similar to results from a previous study (Nail, Eltiganni, \& Islam, 2008). The reason for this is unknown, though it may not be unaffected by occupational exposures or poor health seeking behaviours in that age group. Furthers studies are needed to clarify this.

A similar Nigerian study reported a higher prevalence of antibodies to HCV in HCWs compared with blood donors, but they were a non-representative self-selected group and persons with high risk behaviour were excluded (Deuffic-Burban, Delarocque-Astagneauc, Abiteboul, Bouvet, \& Yazdanpanah, 2011).

In this study, some HCWs were categorized as "others"; heath assistants, health clerks, dental therapist, mortuary attendants whose duties ranged from sample receptions, equipment clean ups, sample handling and transportation, trash disposal the highest prevalence for HCV was among this group; Our study also showed that absence of antibodies to HCV in laboratory technologists, This was consistent with a study that was done among HCWs in Iran and Sudan (Morowatishaifabad, ZareSakhvidi, Gholianavval,, MasoudiBoroujeni, \& Alavijeh, 2015; Luksamijarulkul, Thammata, \& Tiloklurs, 2002). Reasons for this could be due to biosafety practices in laboratories Doctors and nurses both recorded a prevalence of $0.3 \%$, this was low compared to a similar Nigerian study done in Ibadan where an absence of HCV antibodies was reported among doctors and dentists (Olubuyide et al., 1997).

A Dutch study reported prevalence $(0.14 \% ; 95 \%$ confidence interval $[\mathrm{CI}]:<0.01 \%$ to $0.85 \%)$ among $\mathrm{HCWs}$ that perform exposure prone procedures (Zaaijer, Appelman, \& Frijstein, 2012). This draws attention to the increased risk associated to some procedures and the need for more health education and biosafety trainings for those group of HCWs.

Our study showed that educational levels, professional categories, and previous specific trainings on hepatitis $\mathrm{C}$ significantly affected the prevalence of HCV amongst HCW in our institution. A study done in Thailand reported literacy levels and place of residency (urban vs. rural) as independent predictors of HCV transmission (Nawab, 2019). An Italian study equally reported that previous exposure to specific training programme significantly affected nurses' practice in handling haemodialysis patient although this study did not assess the sero status of these nurses (Bianco, Bova, Nobile, Pileggi, \& Pavia, 2013). In our study we found that health attendants, morticians, dental therapist were the most group of health workers affected. Education programme organized in our institution targeted doctors, nurses and laboratory personnel may have contributed to low seroprevalence among these groups. Disparity in health education and biosafety training programme among HCWs could be contributory and future studies are needed to check their effect of on seroprevalence of HCV. 
The risk posed to patients by an HCV infected HCW is not known and there are no current national guidelines to assist in their management. Negligent medical practices, poor infection control procedures and sharing of needles and sharps have been implicated in reports of transmission to patients (Thompson et al., 2009; Cody et al., 2002). There has been only a single published report of HCV transmission to a patient from an infected cardiac surgeon in Europe despite observing universal safety precautions (Esteban, Sauleda, \& Quer, 2008). There is no published report of such transmission to patients from our institution or in Nigeria in general.

In 2015 Nigeria launched her national policy on hepatitis prevention with nation wide mass awareness programme and screening (Zaggi, 2015) which resulted in improved public awareness and avoidance of high-risk behaviours through health education programmes. This agrees with a meta-analysis report which suggested that prevalence of HCV infection may have reduced due to improved prevention (Westermann, Peters, Lisiak, Lamberti, \& Nienhaus, 2015). The relatively low prevalence rate of HCV reported in this study may not be unrelated to the successful outcome of this programme increased health education and awareness of hepatitis nation-wide.

\subsection{Limitations}

This study only assayed antibodies to HCV. Hepatitis C viral DNA detection was not done hence individuals still in the window period (the period between infection and the time the body produces detectable antibodies to hepatitis $\mathrm{C}$ virus using an antibody test protocol) of hepatitis $\mathrm{C}$ seropositivity could not be detected using this screening methodology. Again some data of interest such as history of occupational exposure, blood transfusion and liver histology were not available due to recall bias

\section{Conclusion/Recommendation}

The study revealed that Hepatitis C seropositivity was low among health care workers and most had good knowledge of hepatitis $\mathrm{C}$ virus, its risk factors and mode of transmission. Educational levels, professional categories and previous training were independently associated with hepatitis $\mathrm{C}$ seropositivity.

There is need to bridge any disparity in health education training of hepatitis among HCWs and to avoid complacency among HCWs, continuing medical education and pre-employment hepatitis tailored awareness and prevention program should be sustained in hospitals in Nigeria.

\section{Competing Interests Statement}

The authors declare that there are no competing or potential conflicts of interest.

\section{References}

Adegoke, O. A., Kolawole, B. A., Ikem, R. T., Adediran, A., Aboderin, A. O., \& Salawu, A. (2008). Seroprevalence of hepatitis c virus infection in Nigerians with type 2 diabetes mellitus. Nigerian Journal of Clinical Practice, 11(3), 199-201.

Anaedobe, C., Nwadike, V., \& Fowotade, A. (2016). Hepatitis C Virus Infection among Pregnant Women in Ibadan, Nigeria: Prevalence, Correlates and Co-infection with HIV. International Journal of Tropical Disease\& Health, 14(1), 1-11. https://doi.org/10.9734/IJTDH/2016/23584

Ayolabi, C. I., Taiwo, M. A., Omilabu, S. A., Adebisi, A. O., \& Fatoba, O. M. (2006). Seroprevalence of hepatitis C virus among blood donors in Lagos Nigeria. African journal of Biotechnology, 5, 1944-1946.

Bianco, A., Bova, F., Nobile, C. G., Pileggi, C., \& Pavia, M. (2013). Healthcare workers and prevention of hepatitis $\mathrm{C}$ virus transmission: exploring knowledge, attitudes and evidence-based practices in hemodialysis units in Italy. BMC Infect Dis, 76. https://doi.org/10.1186/1471-2334-13-76

Chen, S. L., \& Morgan, T. R. (2006). The Natural History of Hepatitis C Virus (HCV) Infection. International Journal of Medical Sciences, 3(2), 47-52. https://doi.org/10.7150/ijms.3.47

Cody, S. H., Nainan, O. V., \& Garfein, R. S. (2002). Hepatitis C virus transmission from an anesthesiologist to a patient. Arch Intern Med, 162, 345-50. https://doi.org/10.1001/archinte.162.3.345

Coppola, N., De Pascalis, S., Onorato, L., Calò, F., Sagnelli, C., \& Sagnelli, E. (2016). Hepatitis B virus and hepatitis C virus infection in healthcare workers. World $J$ Hepatol, 8, 273-281. https://doi.org/10.4254/wjh.v8.i5.273

Deuffic-Burban, S., Delarocque-Astagneauc, E., Abiteboul, D., Bouvet, E., \& Yazdanpanah, Y. (2011). Blood-borne viruses in health care workers: Prevention and management. $J$ Clin Virol, 52, 4-10. https://doi.org/10.1016/j.jcv.2011.05.016

Dore, G. J., Ward, J., \& Thursz, M. (2014). Hepatitis C disease burden and strategies to manage the burden (Guest 
Editors Mark Thursz, Gregory Dore and John Ward). $J$ Viral Hepat, 21(Suppl 1), 1-4. https://doi.org/10.1111/jvh.12253

Eke, C. B., Ogbodo, S. O., Ukoha, O. M., Muoneke, V. U., Ibekwe, R. C., \& Ikefuna, A. N. (2016). Seroprevalence and Correlates of Hepatitis C Virus Infection in Secondary School Children in Enugu, Nigeria. Ann Med Health Sci Res, 6(3), 156-161. https://doi.org/10.4103/2141-9248.183940

Esteban, J. I., Sauleda, S., \& Quer, J. (2008). The Changing Epidemiology of Hepatitis C Virus Infection in Europe. Journal of Hepatology, 48, 148-162. https://doi.org/10.1016/j.jhep.2007.07.033

Franco, E., Bagnato, B., Marino, M. G., Meleleo, C., Serino, L., \& Zaratti, L. (2012). Hepatitis B: Epidemiology and prevention in developing countries. World J Hepatol, 4, 74-80. https://doi.org/10.4254/wjh.v4.i3.74

Hughes, H. Y., \& Henderson, D. K. (2016). Postexposure prophylaxis after hepatitis C occupational exposure in the interferon-free era. Curr Opin Infect Dis, 29(4), 373-380. https://doi.org/10.1097/QCO.0000000000000281

Jemilohun, A. C., Oyelade, B. O., \& Oiwoh, S. O. (2014). Prevalence of Hepatitis C Virus Antibody Among Undergraduates in Ogbomoso, Southwestern Nigeria. Afr $J$ Infect Dis, 8(2), 40-43. https://doi.org/10.4314/ajid.v8i2.5

Kateera, F., Walker, T. D., Mutesa, L., Mutabazi, V., Musabeyesu, E., Mukabatsinda, C., ... \& Orikiiriza, J. T. (2015). Hepatitis B and C seroprevalence among health care workers in a tertiary hospital in Rwanda. Transactions of the Royal Society of Tropical Medicine and Hygiene, 109(3), 203-208. PMID: 25636951; PMCID: PMC4321023. https://doi.org/10.1093/trstmh/trv004

Kim, W. R., Ward, J. W., Cheever, L. W., Dan, C., Dee, L., \& Zola, J. (2010). Transforming the current infrastructure for combating HBV and HCV infections. J Fam Pract, 59, S65- S70.

Lavanchy, D. (2011). Evolving epidemiology of hepatitis C virus. Clinical Microbiology and Infection, 17(2), 107-115. https://doi.org/10.1111/j.1469-0691.2010.03432.x

Luksamijarulkul, P., Thammata, N., \& Tiloklurs, M. (2002). Seroprevalence of hepatitis B, hepatitis C and human immunodeficiency virus among blood donors, Phitsanulok Regional Blood Center, Thailand. Southeast Asian journal of tropical medicine and public health, 33, 272-279.

Mitchell, A. E., Colvin, H. M., \& Palmer, B. R. (2010). Institute of Medicine recommendations for the prevention and control of hepatitis B and C. Hepatology, 51, 729-733. https://doi.org/10.1002/hep.23561

Mohd Hanafiah, K., Groeger, J., Flaxman, A. D., Wiersma, S. T., Abraham, D. F., \& Stephen, T. W. (2013). Global epidemiology of hepatitis $\mathrm{C}$ virus infection: New estimates of age-specific antibody to HCV seroprevalence. Hepatology, 57, 1333-1342. https://doi.org/10.1002/hep.26141

Morowatishaifabad, M. A., ZareSakhvidi, M. J., Gholianavval, M., MasoudiBoroujeni, D., \& Alavijeh, M. M. (2015). Predictors of Hepatitis B Preventive Behavioral Intentions in Healthcare Workers. Saf Health Work, 6(2), 139-142. https://doi.org/10.1016/j.shaw.2014.12.001

Nail, A., Eltiganni, S., \& Islam, A. (2008). Seroprevalence of Hepatitis B and C among health care workers in Omdurman, Sudan. Sudan JMS, 3, 201-207. https://doi.org/10.4314/sjms.v3i3.38536

Nawab, M. (2019). Seroprevalence of Hepatitis C Virus (Case in District Mardan, Pakistan). International Journal of Health, Nursing, \& Medicine, 1, 40 - 41

Okasha, O., Munier, A., Delarocque Astagneau, E., El Houssinie, M., Rafik, M., Bassim, H., ... \& Fontanet, A. (2015). Hepatitis C virus infection and risk factors in health-care workers at Ain Shams University Hospitals, Cairo, Egypt. EMHJ-Eastern Mediterranean Health Journal, 21(3), 199-212. https://doi.org/10.26719/2015.21.3.199

Olubuyide, I. O., Ola, S. O., Aliyu, B., Dosumu, O. O., Arotiba, J. T., Olaleye, O. A., ... \& Olawuyi, F. (1997). Hepatitis B and C in doctors and dentists in Nigeria. QJM: monthly journal of the Association of Physicians, 90(6), 417-422. https://doi.org/10.1093/qjmed/90.6.417

Onwere, S., Kamanu, C. I., Chigbu, B., Okoro, O., Ndukwe, P., Akwuruoha, E., ... \& Onwere, A. (2011). Hepatitis $\mathrm{C}$ virus infection in pregnant women in Southeastern Nigeria. Journal of Obstetrics and Gynaecology of Eastern and Central Africa, 23(1), 26-29.

Pennap, G. R., Yakubu, A., Odula, O., \& Joseph, F. J. (2010). Prevalence of hepatitis B and C virus infection among people of a local community in Keffi, Nigeria. African Journal of Microbiology Research, 4(4), 
274-278.

Perz, J. F., Armstrong, G. L., Farrington, L. A., Hutin, Y., \& Bell, B. P. (2006). The contributions of hepatitis B virus and hepatitis $\mathrm{C}$ virus infections to cirrhosis and primary liver cancer worldwide. J Hepatol, 45, 529-538. https://doi.org/10.1016/j.jhep.2006.05.013

Peters, M. G., Weinbaum, C., Tan, L., Baine, W. B., Dienstag, J. L., Liang, T. J., \& So, S. (2010). Activity 4: Recommendations for prevention, screening, and diagnosis of HBV and HCV infections. Journal of Family Practice, 59(SUPPL. 4).

Smith, D. B., Mellor, J., Jarvis, L. M., Davidson, F., Kolberg, J., Urdea, M., ... \& International HCV Collaborative Study Group. (1995). Variation of the hepatitis C virus $5^{\prime}$ non-coding region: implications for secondary structure, virus detection and typing. Journal of general virology, 76(7), 1749-1761. https://doi.org/10.1099/0022-1317-76-7-1749

Thompson, N. D., Hellinger, W. C., Kay, R. S., Cohen, L., Ragan, P., Voss, R. A., ... \& Perz, J. F. (2009). Healthcare-associated hepatitis $\mathrm{C}$ virus transmission among patients in an abdominal organ transplant center. Transplant Infectious Disease, 11(4), 324-329. https://doi.org/10.1111/j.1399-3062.2009.00406.x

Thorburn, D., Dundas, D., McCruden, E. A. B., Cameron, S. O., Goldberg, D. J., Symington, I. S., ... \& Mills, P. R. (2001). A study of hepatitis C prevalence in healthcare workers in the West of Scotland. Gut, 48(1), 116-120. https://doi.org/10.1136/gut.48.1.116

Wasley, A., Miller, T., \& Finelli, L. (2007). Surveillance for acute viral hepatitis: United State. MMWR., 56(SS03), 1-24. Retrieved January 31, 2018, from www.cdc.gov/mmwr/ preview/mmwrhtml/ss5603a1.htm

Watanabe, H., Saito, T., Shinzawa, H., Okumoto, K., Hattori, E., \& Adachi, T. (2003). Spontaneous elimination of Serum Hepatitis C Virus RNA in Chronic HCV Carriers: A population based cohort study. J. Med. Virol, 71, 56-61. https://doi.org/10.1002/jmv.10448

Westermann, C., Peters, C., Lisiak, B., Lamberti, M., \& Nienhaus, A. (2015). The prevalence of hepatitis C among healthcare workers: a systematic review and meta-analysis. Occup Environ Med, 72(12), 880-888. https://doi.org/10.1136/oemed-2015-102879

World Health Organization. (2018). Global Hepatitis Report. Geneva, 1-83. Retrieved June $12^{\text {th }}, 2018$, from http://www.who.int/hepatitis/publications/global-hepatitis-report2017/en/

Zaggi, H. (2015). Federal Ministry of Health, Nigeria: FG Launches National Policy on Hepatitis. Retrieved February 3, 2018, from http://allafrica.com/stories/201507310394.html

Zaaijer, H. L., Appelman, P., \& Frijstein, G. (2012). Hepatitis C virus infection among transmission-prone medical personnel. European Journal of Clinical Microbiology \& Infectious Diseases, 31(7), 1473-1477. https://doi.org/10.1007/s10096-011-1466-9

\section{Copyrights}

Copyright for this article is retained by the author(s), with first publication rights granted to the journal.

This is an open-access article distributed under the terms and conditions of the Creative Commons Attribution license (http://creativecommons.org/licenses/by/4.0/). 